\title{
CORRECTION OF ACIDOSIS IN THE RESUSCITATION OF THE COLLAPSED CHILD
}

\author{
BY \\ M. E. DODSON and A. L. STEAD \\ From the Department of Anaesthesia, Alder Hey Children's Hospital, Liverpool
}

(RECEIVED FOR PUBLICATION NOVEMBER 17, 1964)

We present the case histories of 4 severely ill children in whom the decisive factor in survival was thought to have been the correction of their metabolic acidosis with sodium bicarbonate. In 3 of the cases respiratory failure was probably mainly responsible for the child's collapse.

\section{Methods}

The biochemical estimations were made on capillary blood samples using a Vibron $p \mathrm{H}$ meter with a RobinsonMattock electrode. It is appreciated that the figures given are only a measurement of the metabolic state of the blood at the site from which it was drawn. From other experiments the authors know that the figures are sufficiently accurate, however, to form a basis for clinical treatment, as 3 of these 4 cases confirm.

Case 1. S.H., age 3 years, weight $15 \mathrm{~kg}$., had injured his hip five days previously, and was admitted in a semiconscious state. A diagnosis of septic arthritis of the hip and septicaemia was made. Within an hour, and despite $200 \mathrm{ml}$. plasma, his pulse and blood pressure became unrecordable. He was cyanosed and in severe peripheral circulatory failure. A further $200 \mathrm{ml}$. plasma and $400 \mathrm{ml}$. blood with intravenous hydrocortisone, Methedrine, and oxytetracycline were given. Oxygen was administered continuously. His condition, however, continued to deteriorate, and his pupils became widely dilated and unreactive.

With difficulty, enough capillary blood was obtained to estimate his base deficit, which was found to be $20 \mathrm{mEq} / 1$. $60 \mathrm{mEq}$ sodium bicarbonate were given rapidly intravenously and his peripheral circulation improved slightly. Repeated estimations showed a decreasing base deficit which was steadily corrected by a further $60 \mathrm{mEq}$ bicarbonate given over the following 3 hours (Table 1); $5 \frac{1}{2}$ hours after admission, his pupils were of normal size and reacting to light, he responded to painful stimuli, and his systolic blood pressure was $90 \mathrm{~mm}$. Hg.

His convalescence was prolonged but he slowly recovered complete cerebral function. This case is reported more fully elsewhere (Ellis and Dodson, 1964).
Case 2. J.E., age 3 weeks, weight $1 \cdot 8 \mathrm{~kg}$., a premature baby, was admitted with urinary retention due to urethral valves. His blood urea was $260 \mathrm{mg}$. $/ 100 \mathrm{ml}$. Under anaesthesia the urethral valves were resected.

Next morning, he collapsed and became cyanosed with laboured respirations and impalpable pulse. It was thought that he had regurgitated and inhaled vomit. He improved slightly after intubation and inflation with oxygen, but there was no obvious respiratory cause for his collapse. His metabolic state was therefore assessed, and the $p \mathrm{H}$ was found to be $6 \cdot 69$. This was so low that the base deficit could not be estimated from the Siggaard Andersen and Engel nomogram. His alkali reserve was $8 \mathrm{mEq} / \mathrm{l}$. and he was given $4.5 \mathrm{mEq}$ bicarbonate intravenously. One hour later, the $p \mathrm{H}$ was $6 \cdot 70$.

Within $6 \frac{1}{2}$ hours of his first $p \mathrm{H}$ measurement, he had received $22 \mathrm{mEq}$ bicarbonate; the $p \mathrm{H}$ was then 7.07 and base deficit $20.5 \mathrm{mEq} / \mathrm{l}$. The further bicarbonate required to correct this is shown in Table 2.

It is interesting that his temperature was $87^{\circ} \mathrm{F} .\left(30 \cdot 5^{\circ}\right.$ C.) when he was extremely acidotic, and the reduction in metabolism which this produced, may have contributed to his survival (Clowes, Neville, Sabga, and Shibota, 1958).

Twelve hours after his initial collapse, when his condition had been considered hopeless, he was lively and a good colour. Next day, the $p \mathrm{H}$ was $7 \cdot 3$ and his metabolic state was normal. Should he require further surgery, his acid-base state will be observed closely.

Case 3. A.M., aged 1 day, weight $2 \cdot 3 \mathrm{~kg}$., was cyanosed from birth and was operated on for a supposed diaphragmatic hernia when 12 hours old.

At operation, no hernia was found, but there were numerous cysts of the lower lobe of the left lung, a condition that can produce a similar radiological picture. The left upper lobe was collapsed and could not be inflated. The cystic lobe was resected and an intrapleural drain was inserted. The child's immediate post-operative condition was satisfactory.

Next day she was semi-conscious and cyanosed, with irregular grunting respirations at a rate of 90 , indicating severe respiratory insufficiency. Her pulse was 170, and she was in peripheral circulatory failure. At this time, 18 hours after operation, the $p \mathrm{H}$ was $7 \cdot 17, \mathrm{PCO}_{2} 40 \mathrm{~mm}$. 
TABLE 1

CASE 1: CORRECTION OF ACIDOSIS BY INTRAVENOUS SODIUM BICARBONATE

\begin{tabular}{|c|c|c|c|c|c|c|}
\hline \multicolumn{2}{|c|}{ Date and Time } & \multirow{2}{*}{$\begin{array}{l}p \mathrm{H} \\
\\
7 \cdot 30 \\
7 \cdot 40 \\
7 \cdot 45 \\
7 \cdot 45\end{array}$} & \multirow{2}{*}{$\begin{array}{l}\mathrm{PCO}_{2}(\mathrm{~mm} . \mathrm{Hg}) \\
\\
30 \\
26 \\
23 \cdot 5 \\
21\end{array}$} & \multirow{2}{*}{$\begin{array}{c}\begin{array}{c}\text { Standard } \\
\text { Bicarbonate } \\
\text { (mEq/l.) }\end{array} \\
11.6 \\
16.0 \\
19.0 \\
20.5 \\
20.5\end{array}$} & \multirow{2}{*}{$\begin{array}{c}\begin{array}{c}\text { Base Deficit } \\
(\mathrm{mEq} / \mathrm{l} .)\end{array} \\
20 \\
10 \\
6 \\
3 \\
0\end{array}$} & \multirow{2}{*}{$\begin{array}{c}\begin{array}{r}\text { Bicarbonate } \\
\text { Given (mEq) }\end{array} \\
60 \\
30 \\
55 \\
0 \\
0\end{array}$} \\
\hline $\begin{array}{l}27.6 .63 \\
28.6 .63\end{array}$ & $\begin{array}{c}3.45 \text { p.m. } \\
4.40 \text { p.m. } \\
6.0 \text { p.m. } \\
11.30 \text { p.m. } \\
9.30 \text { a.m. }\end{array}$ & & & & & \\
\hline
\end{tabular}

TABLE 2

CASE 2: CORRECTION OF ACIDOSIS BY INTRAVENOUS SODIUM BICARBONATE

\begin{tabular}{|c|c|c|c|c|c|}
\hline Date and Time & $p \mathbf{H}$ & $\mathrm{PCO}_{2}(\mathrm{~mm} . \mathrm{Hg})$ & $\begin{array}{c}\text { Standard } \\
\text { Bicarbonate }\end{array}$ & $\begin{array}{c}\text { Base Deficit } \\
(\mathrm{mEq} / \mathrm{l} .)\end{array}$ & $\begin{array}{l}\text { Bicarbonate } \\
\text { Given (mEq) }\end{array}$ \\
\hline $\begin{array}{ll}3.10 .63 & \left\{\begin{array}{l}2.45 \text { p.m. } \\
4.0 \text { p.m. } \\
9.15 \text { p.m. }\end{array}\right. \\
4.10 .63 & 9.30 \text { a.m. }\end{array}$ & $\begin{array}{l}6 \cdot 69 \\
6 \cdot 70 \\
7 \cdot 07 \\
7 \cdot 3\end{array}$ & $\begin{array}{l}34 \\
45\end{array}$ & $\begin{array}{l}10 \cdot 5 \\
20\end{array}$ & $\begin{array}{c}20 \cdot 5 \\
4\end{array}$ & $\begin{array}{c}4 \cdot 5 \\
18 \\
9 \\
0\end{array}$ \\
\hline
\end{tabular}

TABLE 3

CASE 3: CORRECTION OF ACIDOSIS BY INTRAVENOUS SODIUM BICARBONATE

\begin{tabular}{|c|c|c|c|c|c|c|}
\hline \multicolumn{2}{|c|}{ Date and Time } & \multirow{2}{*}{$\begin{array}{l}p \mathrm{H} \\
7 \cdot 17 \\
7 \cdot 32 \\
7 \cdot 32 \\
7 \cdot 36\end{array}$} & \multirow{2}{*}{$\begin{array}{c}\mathrm{PCO}_{2}(\mathrm{~mm} . \mathrm{Hg}) \\
40 \\
33 \\
34 \\
45\end{array}$} & \multirow{2}{*}{$\begin{array}{c}\begin{array}{c}\text { Standard } \\
\text { Bicarbonate } \\
\text { (mEq/l.) }\end{array} \\
14 \\
17 \cdot 5 \\
15 \\
23\end{array}$} & \multirow{2}{*}{$\begin{array}{c}\begin{array}{c}\text { Base Deficit } \\
\text { (mEq/1.) }\end{array} \\
15 \\
7 \\
13 \\
0\end{array}$} & \multirow{2}{*}{$\begin{array}{r}\begin{array}{r}\text { Bicarbonate } \\
\text { Given (mEq) }\end{array} \\
4 \cdot 5 \\
4 \cdot 5 \\
9 \\
0\end{array}$} \\
\hline 12.12 .63 & $\begin{array}{c}12.30 \text { p.m. } \\
3.0 \text { p.m. } \\
7.30 \text { p.m. } \\
11.0 \text { p.m. }\end{array}$ & & & & & \\
\hline
\end{tabular}

$\mathrm{Hg}$, and the base deficit $15 \mathrm{mEq} / \mathrm{l}$. Sodium bicarbonate was given intravenously to correct this partially, and $2 \frac{1}{2}$ hours later, the base deficit had decreased to $7 \mathrm{mEq} / \mathrm{l}$. Following this, her clinical condition deteriorated again, and this corresponded with an increase in the acidosis (Table 3), requiring further bicarbonate therapy. She thereafter made an uninterrupted recovery.

Case 4. K.F., aged 8 weeks, weight $4 \mathrm{~kg}$. This case illustrates that it can be reasonable to give sodium bicarbonate in the absence of measured $p \mathrm{H}$ changes.

On the morning of admission, this baby became ill at home, and was described by the mother as "listless and breathing badly'. In the ambulance on the way to hospital he deteriorated further, becoming cyanosed, and by the time he reached the ward at midday he was gasping occasionally and had an irregular bradycardia. External cardiac massage was applied until the child could be intubated and inflated with oxygen. His heart rate and respiration then improved, but he remained cyanosed and began to have continuous convulsions. His temperature was $103^{\circ} \mathrm{F}$. $\left(39 \cdot 5^{\circ} \mathrm{C}\right.$. $)$ and he was very dehydrated.

Intravenous fluids were started and in view of the gravity of his clinical state, his base deficit was assumed to be at least 5-10 mEq/1. $150 \mathrm{ml}$. plasma and $6 \mathrm{mEq}$ bicarbonate were given over the next $1 \frac{1}{2}$ hours and by this time his colour was much better. He had peripheral pulses and though his limbs were stiff, he only twitched occasionally. He was breathing well, but was nursed in moist oxygen with the endotracheal tube in place for a further hour. The tube was then removed and he started to take feeds eagerly.

Over the next 24 hours, cyanosis disappeared, and two weeks after admission he was ready for discharge. During this time his prepuce sloughed, an indication of the severity of the initial peripheral circulatory failure. The aetiology of this child's fulminating illness remains obscure.

\section{Discussion}

Many varied disease processes may produce a state of metabolic acidosis, poor tissue perfusion being the common factor in these conditions. Tissue perfusion is dependent upon capillary blood flow, which in itself depends on such factors as arterial pressure, vasoconstriction and blood viscosity.

Many conditions influence these factors. Among them are hypoxia, hypercarbia; severe infections and toxaemias; the occlusion of major arteries; cardiac failure; hypovolaemia and hypotension.

The reduced tissue perfusion results in lowered oxygen supply to the tissues and accumulation of metabolites, including lactic and pyruvic acids. 
These cause a fall in tissue and later in blood $p \mathrm{H}$. This fall in $p \mathrm{H}$, especially if it is accompanied by decreased arterial oxygen tension, is followed by depression of cardiac and vasomotor function. If the acidosis is allowed to persist, a stage will be reached where, though the metabolic disturbance is corrected, death still occurs (Thrower, Darby, and Aldinger, 1961).

Several conditions contributed to the production of the acidosis in the four patients quoted.

Case 1 was hypotensive and hypovolaemic. The hypotension that occurs in severe infections and septic shock is due mainly to vascular changes. Following loss of vasomotor control, redistribution of blood takes place, with reduced venous return and cardiac output (Gilbert, 1960). In addition to these vascular changes, this child had also lost fluid from his circulation into the affected leg.

Cases 2 and 4 were dehydrated, and renal function was depressed in Case 2. Both children had almost stopped breathing when first seen, and cardiac arrest appeared to be imminent in Case 4. Hypoxia, hypercarbia, and low cardiac output were, therefore, contributory factors. Clowes, Sabga, Konitaxis, Tomin, Hughes, and Simeone (1961) have demonstrated the high mortality, experimentally and clinically, of a combination of hypoxia and hypercapnia, and also showed that hypoxia alone produces more severe metabolic and circulatory changes than hypercapnia alone. Case 3, who was cyanosed from birth, was hypoxic and probably also hypercapnic before operation. At operation, oxygenation was improved and $\mathrm{CO}_{2}$ removed by ventilation with a $50: 50$ nitrous oxide-oxygen mixture. This temporarily improved the metabolic and respiratory acidosis, but after operation, the hypoxia recurred and with it a metabolic acidosis.

Treatment of Acidosis. The correction of the acidosis should be started as early as possible. Enzymes are active only within a narrow range of $p \mathrm{H}$ and are inhibited and ultimately destroyed at $p \mathrm{H}$ 's beyond these limits (Carter and Thompson, 1959).

Using the formula $0.3 \times$ body weight $(\mathrm{kg}$.) $\times$ base deficit (Astrup, Jørgensen, Andersen, and Engel, $1960)$, the bicarbonate ( $\mathrm{mEq}$ ) required was calculated. The strength of the sodium bicarbonate was $2.5 \%$. This is a hypertonic solution containing approximately $300 \mathrm{mEq} / \mathrm{l}$. No venous damage from this solution has been seen, but $5 \% \mathrm{NaHCO}_{3}$ has caused erythema when injected into small veins. The usefulness of hypertonic solutions in states of metabolic acidosis has recently been emphasized by Brooks, Williams, Manley, and Whiteman (1963). An article in the Lancet (1963) suggests that these solutions may act by preventing the passage of sodium ions and water into damaged cells. Sodium bicarbonate is the logical choice as it is the most important buffer of the plasma.

Two other buffers may be considered.

(a) Tris-hydroxy-amino-methane. This hydrogen ion acceptor is effective in restoring $p \mathrm{H}$ but may have other undesirable effects (Kaplan and Fox, 1961). It could be of use in cases where the administration of large quantities of sodium with bicarbonate is undesirable, e.g. Case 2, where kidney function was depressed.

(b) Sodium lactate. This widely used substance was originally introduced as an alternative to bicarbonate in solutions given by the intraperitoneal and subcutaneous routes, as the $p \mathrm{H}$ of bicarbonate solutions was too high for this purpose (Amer. $J$. Med., 1962). Now that the intravenous route is so readily available, it is illogical to use sodium lactate in cases of severe metabolic acidosis. Oxygen required to convert the lactate to bicarbonate is not likely to be readily available, and the delay in effective treatment while this oxidation is taking place will be hazardous.

\section{Summary and Conclusions}

Four cases are described of very ill children who received sodium bicarbonate to correct their metabolic acidosis.

The factors that may lead to the production of a metabolic acidosis are discussed and its treatment is outlined.

Metabolic acidosis frequently presents primarily as a respiratory problem, as it did in 3 of the cases. It should always be considered as a possible factor when the patient does not respond to other resuscitative measures. The failure of many cases of 'irreversible' shock to respond to treatment may be due to failure to correct an acidotic state.

While a $p \mathrm{H}$ meter is essential equipment in any modern hospital, it is practicable, if the clinical state indicates prolonged reduced tissue perfusion, to use an assumed base deficit of $5-10 \mathrm{mEq} / 1$. as a basis for treatment.

Our thanks are due to Mr. G. Shatwell, Mr. H.Johnston, Dr. R. Smithells, and Miss I. Forshall, for permission to publish these cases and to the staff of the respiratory unit for the biochemical estimations.

\section{REFERENCES}

Amer. J. Med. (1962). Lactate versus bicarbonate: a reconsideration of the therapy of metabolic acidosis. (Editorial). 32, 831. Astrup, P., Jørgensen, K., Andersen, O. S., and Engel, K. (1960). The acid-base metabolism; a new approach. Lancet, 1, 1035. 
Brooks, D. K., Williams, W. G., Manley, R. W., and Whiteman, P. (1963). Respiratory changes in haemorrhagic shock. Anaesthesia, 18, 363.

Carter, C. W., and Thompson, R. H. S. (1959). Biochemistry in Relation to Medicine, 3rd ed. Longmans, London.

Clowes, G. H. A., Jr., Neville, W. E., Sabga, G., and Shibota, Y. (1958). The relationship of oxygen consumption, perfusion rate, and temperature to the acidosis associated with cardiopulmonary circulatory bypass. Surgery, 44, 220.

, Sabga, G. A., Konitaxis, A., Tomin, R., Hughes, M., and Simeone, F. A. (1961). Effect of acidosis on cardiovascular function in surgical patients. Ann. Surg., 154, 524.
Ellis, W., and Dodson, M. E. (1964). Severe septic shock treated successfully with sodium bicarbonate. J. Bone Jt Surg. 46-B, 746.

Gilbert, R. P. (1960). Mechanisms of the hemodynamic effects of endotoxin. Physiol. Rev., 40, 245.

Kaplan, S., and Fox, R. P. (1961). Amine buffers in the management of respiratory and mixed acidosis. In Transactions of the American Pediatric Society. Amer. J. Dis. Child., 102, 695.

Lancet (1963). Hypertonic sodium for 'irreversible' oligaemic shock. $1,539$.

Thrower, W. B., Darby, T. D., and Aldinger, E. E. (1961). Acid-base derangements and myocardial contractility. Arch. Surg., 82, 56. 